\section{Science Education in Hungary}

\section{Erzsébet Ceglédi17}

2016, Vol. 6(2), 93-98

(C) The Author(s) 2016

http://herj.lib.unideb.hu

Debrecen University Press

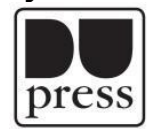

DOI: 10.14413/HERJ.2016.02.07

\begin{abstract}
Examination of the efficacy of science education has been in the forefront of domestic and international research in recent decades. Thirty years ago the efficacy of science education in Hungary was internationally recognised. However, there signs as early as the 1990s that student outcomes were declining in Hungarian students' ability to apply knowledge and problemsolving. Based on the results of the PISA assessments, there were no considerable changes in Hungarian students' knowledge. Besides the overall performance which corresponded to the average, however, it could be observed that Hungarian students' ability to apply knowledge related to experiments and measurements lagged behind that of students in other countries. Based on the results of the 2009 assessment, there is a relatively small number of students with outstanding abilities in the Hungarian student population. The decline in outcomes in 2012 could be explained with the greater number of students with poorer outcomes. Research confirmed that this decline in outcomes can be associated with the predominantly theoretical knowledge of our students and the low efficiency of their ability to apply knowledge. Due to a lack of practice and the employment of ill-matching learning strategies, a more thorough processing of the enormous amount of lexical knowledge taught at school does not take place. All this is further confounded by the fact that our students' sincere interest in sciences decreases with age. Investigations performed over the past years have confirmed that, in order to increase interest in knowledge taught and to improve outcomes, changes need to be introduced in science education.
\end{abstract}

Keywords: science education, student outcomes, learning strategies, interest in subject

17 Erzsébet Ceglédi, Kossuth Lajos Elementary and Secondary Boarding School, Tiszafüred, (Hungary), cegledi_e@freemail.hu 


\section{Introduction}

There have been significant changes in achievements of the Hungarian scientific education in the past few decades. Ever-worsening student outcomes, the low-efficiency level of applicability of students' primarily theoretical knowledge and a decline in the popularity of science subjects (Nahalka, 1999; Csapó, 1999, 2004; Géczi, 2001; D. Balogh, 2002) have become not only generally felt in everyday pedagogical practice but have also manifested themselves measurably in the results of domestic and international research. Analysis of these investigations reveals that the present situation is a consequence of a process that started earlier. Single, as well as short, longitudinal studies reflected only a momentary situation. The ongoing monitoring of the change that had taken place was made possible only through regular international investigations carried out over several years. The assessments did not only verify the changes in student outcomes but also made it possible to compare our students' outcomes with those of learners in other countries. They also provided information about the factors influencing performance (Nahalka, 1999; Csapó, 1999, 2004; Géczi, 2001; D. Balogh, 2002). The joint results of domestic and international investigations called for an exploration of the causes of the changes that had taken place in Hungarian science education and for finding possible solutions.

\section{Changes in students' outcomes in science subjects}

In the 1970's and 80's, Hungarian science education was internationally recognised (Vári et al., 1998; Géczi, 2001; Csapó, 2015). This was partly due to the features of the Hungarian educational system. Learners were taught science subjects fairly early on in their studies, in several lessons a week (Báthory, 2000; Géczi, 2001; Szakály, 2001). However, 1995 TIMSS (Third International Mathematics and Science Study) indicated a decline in student outcomes (Revákné \& Máth, 2002). Except for the 1995 assessments, during IEA (International Association for the Evaluation of Educational Achievement) assessments the results involving the entire test suggested a high degree of knowledge, but the subtests examining scientific thinking did not live up to expectations. The investigation aimed to assess ability to apply acquired knowledge as well as problemsolving ability (Vári et al., 1998; Géczi, 2001; B. Németh, 2003; Vári, 2003).

PISA assessments started in 2000 (Programme for International Student Assessment) aim to assess to what extent 15-year-old learners can apply their knowledge in „reallife" situations (B. Németh, 2003). The assessment aimed to study three domains: reading literacy, mathematical literacy, and scientific literacy PISA is a triennial survey and provides information about the features and achievements of the various countries' educational systems. Each year, one of the domains is given more emphasis compared with the other two (Géczi, 2001; B. Németh, 2003; Vári, 2003; Balázsi et al., 2007, 2010; 
Csapó, 2015). Between 2000 and 2006 there were no significant changes in the outcomes. Hungarian students' outcomes in scientific literacy were on a par with the average outcome of the students of the OECD (Organisation for Economic Co-operation and Development) countries (Balázsi et al., 2007).

The 2006 assessment focussed on learners' ability to apply scientific knowledge. Among the issues investigated were identification of problems in sciences, reasoning behind the phenomena and students' ability to apply scientific evidence. In that assessment Hungary ranked 13-17th in science among the 30 OECD countries. Since averages could be calculated only with a certain margin of error, no exact order was set up among the countries. There is no ignoring the fact that Hungarian students' ability to apply experiments and measurements in practice lags behind that of students in other countries (Balázsi et al., 2007). In the 2009 assessment Hungarian students' outcomes still corresponded to the OECD average. However, a closer examination of the outcome revealed that, behind the "facade” of the average outcome, there was a much more nuanced picture. Six levels of ability were identified during the examination. Learners who reach level six can identify, reason for, and consistently apply their knowledge in various life situations. Their thinking and reasoning skills are outstanding and they are able to solve unknown problems in science (Balázsi et al., 2010). In 2009, this level of ability was reached by $1,1 \%$ of children in OECD countries. This rate was considerably lower in the case of Hungarian students: 0,3\%. If we examine the two highest levels of ability (levels 5 and 6), a similar difference can be observed between the OECD average and the Hungarian outcomes. One of the causes of this phenomenon is a feature of the Hungarian educational system: overshadowed by a focus on teaching enormous amounts of lexical knowledge, there is hardly any time left to devote to the practical application of students' theoretical knowledge, making Hungarian students' knowledge primarily theoretical in nature. Our learners have few opportunities to study tasks taken from or relating to everyday life. There is hardly any relationship between things taught at school and everyday life (B. Németh, 2003). The PISA assessments also find the rate of those learners who do not reach the second level of ability important as this is the level necessary to enter the labour market. In this respect the Hungarian results were better $(14,2 \%)$ compared with the OECD average (18\%). Behind the average-looking overall performance lay the fact that there were relatively few low-achievers and students with outstanding abilities in the Hungarian learner population (Balázsi et al., 2010).

The PISA assessment of 2012 showed a decrease in Hungarian students' outcomes. Their average performance was lower compared with both their 2000-2009 results and the OECD average. All this came despite the fact that in education a process had begun which had tried to compensate for earlier flaws. Research as well as everyday practice called for increasing interest in the subject and employing more varied ways of 
processing teaching material (Csapó, 2004). Our students were among those within EU member states who performed poorer: Hungarian students ranked 19-26th among the 34 OECD countries. Only $0,5 \%$ of Hungarian students reached level six of ability compared with $1,2 \%$ of OECD countries. Although the rate of students with exceptional abilities did not decrease, the number of students with poorer abilities increased: their number had grown to $18 \%$ compared with $14,2 \%$ three years before. Thus the decrease in performance in the field of science subjects was related to an increase in the number of students with poorer performance. The question whether this change is transitory or permanent will be adequately answered only by the outcomes of the 2015 assessment (Balázsi et al., 2013; Csapó, 2015).

Similar changes in the science knowledge of Hungarian students were born out by domestic reports, too (Géczi, 2001; Revákné, 2001, 2010; Revákné \& Máth, 2002; B. Németh, 2003; Máth \& Revákné, 2007). The assessment „Science in everyday life” (B. Németh, 2003: 507.) contained tasks similar to those in the PISA assessment. Some of these were based on knowledge acquired in class but they required students to apply that knowledge to real-life situations. The assessment had two important conclusions. One: Hungarian science education is not particularly effective when ability to apply knowledge to everyday life is considered. Two: tasks are performed with better results by those students „who possess more knowledge and more efficient problem-solving skills and patterns of reasoning" (B. Németh, 2003: 523). Similar results were highlighted by the results of investigations of the problem-solving thinking of secondary school students, too (Revákné, 2001, 2010; Revákné \& Máth, 2002; Máth \& Revákné, 2007). The relationship between successful task solution, the amount of acquired knowledge as well as the application of effective problem-solving and reasoning strategies proved to be decisive (Revákné, 2001, 2010; Revákné \& Máth, 2002; B. Németh, 2003; Máth \& Revákné, 2007).

\section{The role of learning strategies and interest in the subject}

Based on research results it can be concluded that changes need to be introduced in order to improve the efficiency of Hungarian science education. Among the factors affecting outcome special attention should be paid to increasing interest in a subject and finding more efficient ways of mastering knowledge (Nagy, 1999; Csapó, 2004).

Among the causes of the situation described is the fact that although our students learn the teaching material and, if necessary - during written and oral tests - can even recall it, there are very few who can, in fact, apply this lexical knowledge to practice. Students often encounter difficulty even in mastering the material. Most students cannot use learning strategies most befitting the special features of the material. Research has proven that mechanical rote-learning, ever so popular with Hungarian students, is also 
rather strong. Based on the results of a PISA assessment, it was with Hungarian students that memorisation was the most popular in 2000 (Revákné, 2001; B. Németh \& Habók, 2006; Környei, 2008). This can give rise to concern since applicable knowledge can only be mastered using in-depth learning strategies that promote understanding. Without proper strategies a more thorough processing of knowledge does not take place. Important and not important elements of knowledge do not become distinct; new knowledge does not connect to previous knowledge, it becomes fixed in isolation and lack of coherence makes later recall and application more difficult (Nagy, 1999; Csapó, 2004). Due to a lack of time and practice, the enormous amount of information taught by schools does not form a unified system in the students' minds. The relationships and correlations between the various parts are scant and imprecise. No conceptual system is formed that is „both vertically and horizontally accessible” (Nagy, 1999: 263.). This prevents knowledge from becoming real, applicable knowledge (Nagy, 1999).

Interest in the subject strongly affecting performance gradually decreases with age. The PISA assessment of 2000 reported that the instrumental factor was exceptionally high among Hungarian students even by international standards. It is not genuine interest in the material being learnt but rather some external reward or reaching a goal that is the primary purpose of these students. The 2006 PISA assessment tried to explore students' attitude to science subjects not only in a questionnaire but also through the tasks they had to solve (Nagy, 1999; Csapó, 2000; Géczi, 2001; Revákné \& Máth, 2002; B. Németh \& Habók, 2006; Balázsi et al., 2007; Máth \& Revákné, 2007; Környei, 2008). Luckily, there are still subjects among sciences, such as biology, that are not entirely rejected by students. According to a domestic survey (Géczi, 2001), eleventh graders find biology more tiring and difficult than younger students, but they still think it is interesting and important. This can be a starting point for arousing our students' interest in science subjects, if carefully chosen pedagogical methods are used (Csapó, 2000; Géczi, 2001).

\section{References}

B. Németh M. \& Habók A. (2006). A 13 és 17 éves tanulók viszonya a tanuláshoz. [13-17-year-old students' attitude to studying.] Magyar Pedagógia, 106 (2), 83-105.

B. Németh M. (2003). A természettudományos műveltség mérése. [Measuring scientific knowledge.] Magyar Pedagógia, 103 (4), 499-526.

Balázsi I., Ostorics L. \& Szalay B. (2007). PISA2006. Összefoglaló jelentés. A ma oktatása és a jövő társadalma. [PISA 2006. Summary. Today's education and the society of future.] Budapest: Oktatási Hivatal.

Balázsi I., Ostorics L., Szalay B. \& Szepesi I. (2010). PISA2009. Összefoglaló jelentés. Szövegértés tíz év távlatában. [PISA2009. Summary. Reading comprehension in the prospect of 10 years.] Budapest: Oktatási Hivatal. 
Balázsi I., Ostorics L., Szalay B., Szepesi I. \& Vadász Cs. (2013). PISA2012. Összefoglaló jelentés. [PISA2012. Summary.] Budapest: Oktatási Hivatal.

Báthory Z. (2000). Természettudományos nevelésünk. [Our scientific education.] Iskolakultúra, 11 (10), 46-54.

Csapó B. (1999). A tudás minősége. [Quality of knowledge.] Educatio, 3. 473-487.

Csapó B. (2000). A tantárgyakkal kapcsolatos attitűdök összefüggései. [Relations of attitudes regarding school subjects.] Magyar Pedagógia, 100 (3), 343-366.

Csapó B. (2004). Tudás és iskola. [Knowledge and school.] Budapest: Mûszaki Könyvkiadó.

Csapó B. (2015). A magyar közoktatás problémái az adatok tükrében. [Problems of the Hungarian Public Education based on data.] Iskolakultúra, 25 (7-8), 4-17.

D. Balogh I. (2002). Problémamegoldás, alkalmazás és tudásátvitel a középiskolai fizikában. [Problemsolving, application and handover of knowledge in Physics at secondary schools.] Iskolakultúra, 12 (1), 51-62.

Géczi J. (2001). A tanulók biológiai tudásáról (Hetedik és tizenegyedik évfolyamos tanulók tudásszintmérése, Magyarország, Baranya megye, 1999). [About students' knowledge in Biology (Measuring students' skill levels in the 7th and 11th years, Baranya county, Hungary, 1999).] Magyar Pedagógia, 101 (4), 461-483.

Környei L. (2008). Kérdések és válaszok a természettudományos oktatásról. [Questions and answers about scientific education.] Új Katedra, 2008 (10), 2-5.

Máth J. \& Revákné Markóczi I. (2007). A problémaközpontú módszer hatékonysága a középiskolai biológiatanításban. [The efficiency of problem-centred method in teaching biology at secondary schools.] Iskolakultúra, 17 (6-7), 97-113.

Nagy Lászlóné (1999). A biológiai alapfogalmak fejlődése 6 - 16 éves korban. [Improvement of biological rudiments at ages 6-16.] Magyar Pedagógia, 99 (3), 263-288.

Nahalka I. (1999). Válságban a magyar természettudományos nevelés. [Crisis in the Hungarian scientific education.] Új Pedagógiai Szemle, 49 (5), 7-22.

Revákné Markóczi I. (2001). A problémamegoldó gondolkodást befolyásoló tényezők. [Influencing factors on problem-solving thinking.] Magyar Pedagógia, 101 (3), 267-284.

Revákné Markóczi I. \& Máth J. (2002). A természettudományos problémamegoldó gondolkodás fejlesztése a középiskolában. [Developing scientific problem-solving thinking at secondary level.] Új Pedagógiai Szemle, 52 (10), 101-109.

Revákné Markóczi I. (2010). A 9 - 10 éves tanulók természettudományos problémamegoldó stratégiájának vizsgálata. [Investigation of 9-10-year-old pupils' scientific problem-solving strategy.] Magyar Pedagógia, 110 (1), 53-71.

Szakály M. (2001). A természettudományi oktatás eredményességéről. [About successfulness of scientific education.] Iskolakultúra, 11 (9), 104-108.

Vári P. et al. (1998). Jelentés a Monitor '97 felmérésről. [Report of Monitor '97 survey.] Új Pedagógiai Szemle, 48 (1), 82-101.

Vári P. (2003). PISA-vizsgálat 2000. [PISA-test 2000.] Budapest: Műszaki Könyvkiadó. 